\title{
球形貯槽支柱の鋼管ブレース構造の耐震性能に関する研究*
}

\author{
小林 英男 ${ }^{* 1}$, 大野 卓志 ${ }^{* 2}$, 佐野 尊*3, 小山田 賢治 ${ }^{* 2}$
}

\section{Study on Seismic Endurance for Pipe Brace Structures of Spherical Tank Supports}

\author{
Hideo KOBAYASHI ${ }^{*}$, Takashi OHNO, Takeru SANO and Kenji OYAMADA \\ ${ }^{* 1}$ The High Pressure Gas Safety Institute of Japan (KHK) \\ 4-3-13 Toranomon, Minato-ku, Tokyo, 105-8447 Japan
}

\begin{abstract}
As a result of the 2011 Great East Japan Earthquake, a severe fire and explosion accident of spherical tanks for LPG (Liquefied Petroleum Gas) storage occurred at Chiba. The leakage of LPG from the piping was caused by overturn of one of tanks and resulted in fire. Following ductile fracture of steel pipe braces, tank supports collapsed by buckling and the tank overturned by the seismic force. In this study, fracture mechanism of the steel pipe braces is made clear and an inspection of the mechanism is performed by the detailed stress analysis. Finally the present design code for seismic endurance is discussed.
\end{abstract}

Key Words : Spherical Tank, Seismic Performance, Pipe Brace, Equivalent Stress, FEM Analysis

\section{1. 緒言}

2011 年 3 月 11 日 14 時 46 分に発生した東北地方太平洋沖地震を端緒として, コスモ石油(侏千葉製油所におい て, 液化石油ガス (LPG) を貯蔵する複数の球形貯槽の火災爆発事故が起き, 火災は 10 日間継続した ${ }^{(1)}$. 火災 爆発事故の原因は, 球形貯槽 1 基の倒壊による配管系からの LPG の漏えいである. 球形貯槽は, 過大な地震荷重 によって支柱の鋼管ブレースが破断した結果，その後の地震荷重によって支柱が座屈し，倒壊に至った．もちろ ん，支柱と鋼管ブレース構造は，而震設計の対象である.

本研究では，球形販槽支柱の鋼管ブレースの破断事例についてメカニズムを考察し，鋼管ブレース構造の詳細 応力解析によってメカニズムを検証し，さらに現行の耐震設計基準について検討した.

\section{2. 鋼管ブレースの破断事例}

2011 年 3 月 11 日 14 時 46 分に東北地方太平洋沖地震が発生し, コスモ石油(株千葉製油所において, 球形貯槽 1 基の支柱（鋼管，10本）の間に補強として取付けている鋼管ブレース（2 本のブレースの交差構造として 10 組, 合計 20 本）の多くが破断した. 同日 15 時 15 分に茨城県沖地震が発生し，ブレースの補強機能を喪失した支柱が 座屈し, 球形貯槽が倒壊した。地震発生時, 倒壊した貯槽は, 開放検査後の LPG 受入れ準備のため, 満水状態で あった，満水の場合，通常の LPG 満液の場合に比較し，約 2 倍の液重量となる.

鋼管ブレース構造を図 1 に示す ${ }^{(2)}$. 1 本の長尺ブレースに 2 本の短尺ブレースを溶接で取付け，交差する 2 本 のブレースの一体化溶接構造としている，鋼管ブレースの材料は STK400，外径は $216.3 \mathrm{~mm}$ ，厚さは $5.8 \mathrm{~mm}$ であ る. この鋼管ブレース構造を支柱間の補強として，2 本の支柱に溶接で取付けている.

\footnotetext{
* 原稿受付 2013 年 3 月 19 日

*1 正員, 名誉員, 高圧ガス保安協会（广105-8447 東京都港区虎ノ門 4-3-13）

*2 高圧ガス保安協会

*3 正員, 高圧ガス保安協会

E-mail: sano@khk.or.jp
} 
破断は寸べて長尺ブレースに生じ，長尺ブレースの破断によって短尺ブレースの取付け溶接が分離している. 長尺ブレースの破断は完全な延性破壊であり，管形状であるが，十分な伸びと絞り（断面収縮）を示している.

上記の火災爆発事故に至ったブレース破断事例の他に，2 件のブレース損傷事例がある．同じ 2011 年 3 月 11 日の東北地方太平洋沖地震および茨城県沖地震によって, 鹿島石油㑣)鹿島製油所において, 球形貯槽（支柱 12 本） 2 基の鋼管ブレースが損傷した. 1 基はやはり満水状態で，長尺ブレースは 12 本のすべてが損傷した．もう 1 基はブタンの貯蔵中で, 相対寸る位置の 2 本の長尺ブレースが損傷し, 残りの 10 本の長尺ブレースにも軽微な 損傷が認められた．なお， 2 件のブレースの損傷事例がいずれの地震に起因するかは特定されていない. また， 球形貯槽の倒壊などの事故には至らなかった。

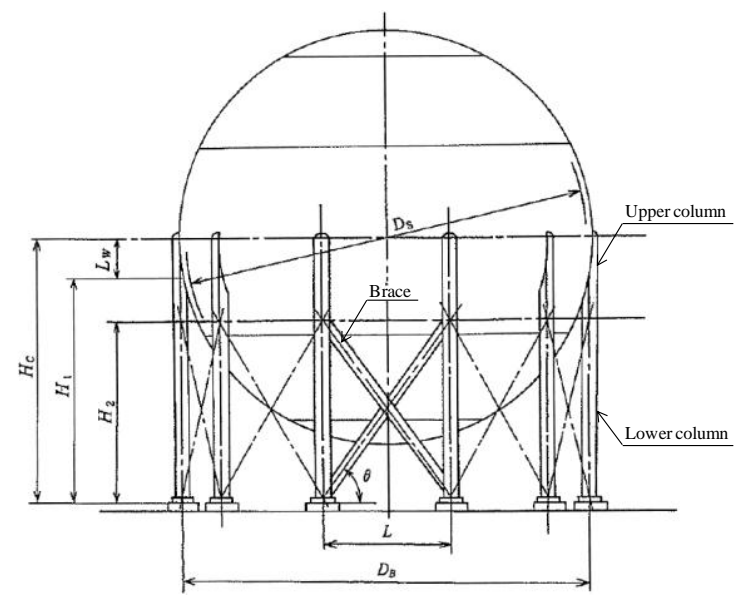

Fig.1 Structure of support columns and pipe braces ${ }^{(2)}$.

\section{3. 耐震設計基準による応力解析}

高圧ガス保安法の適用を受ける球形貯槽は，高圧ガス設備等耐震設計指針，レベル 1 耐震性能評価（以下，耐 震設計基準という）に基づき耐震設計を行う (2). 倒壊した球形貯槽は, 1982 年通達を満足する而震性能を有して いた．ただし，運転重量としては，軽量の LPGの場合であり，満水の場合は考慮していない，以下では，耐震設 計基準に基づき，鋼管ブレースの応力を解析した結果を示す.

耐震設計基準では，ブレースをタイロッドブレースと鋼管ブレースに分類している．しかし，応力解析に用い る式は両者に対して基本的に同じであり，交差する 2 本のブレースをそれぞれ独立とみなす．実際には，鋼管ブ レースは一体化溶接構造であり，交差する 2 本のブレースは独立ではない，しかし，耐震設計基準では，このこ とが明示されていない.

上部支柱に作用する圧縮力 $P_{\mathrm{v}}$ は, 次式で与えられる.

$$
P_{V}=\frac{1}{n}\left\{W_{V}+F_{V}+\frac{4 L\left(H_{c}-H_{2}\right) F_{H}}{D_{B}^{2}}\right\}
$$

ここで, $n$ は支柱の本数， $W_{V}$ は運転重量， $F_{V}$ は設計鉿直地震力， $F_{H}$ は設計水平地震力, $L$ は隣接寸る支柱間の距 離, $H_{c}$ はベースプレートから球款の中心までの高さ, $H_{2}$ はベースプレートからブレース取付け位置までの高さ, $D_{B}$ は支柱の中心を通る円の直径である.

上部支柱に作用寸るせん断力 $S_{\mathrm{H}}$ は，次式で与えられる。

$$
S_{\mathrm{H}}=\frac{4 \sqrt{C_{1}} E A K_{\mathrm{C}} F_{\mathrm{H}}}{\left(C_{2} E A+4 L K_{\mathrm{C}}\right) K}
$$


ここで， $C_{1}$ と $C_{2}$ は $H_{2} / H_{1}$ で決まる定数， $H_{1}$ は支柱の有効高さ， $A=2 A_{\mathrm{B}} \cos ^{3} \theta, A_{\mathrm{B}}$ はブレースの断面積， $\theta$ はブレー スの仰角, $K_{\mathrm{C}}=3 E I_{\mathrm{C}} / H_{1}{ }^{3}, E$ は下部支柱の材料の縦弾性係数, $I_{\mathrm{C}}$ は下部支柱の断面 2 次モーメント, $K$ は水平剛性 $\left(1 / K=1 / K_{1}+1 / K_{2}\right), K_{1}$ は支持構造部全体の曲げ剛性， $K_{2}$ は支持構造部全体のせん断剛性である.

交差する 2 本のブレースには, それぞれ引張応力と圧縮応力が生じる. 引張応力 $\sigma_{\mathrm{t}}$ と圧縮応力 $\sigma_{\mathrm{c}}$ は, 次式で与 えられる.

$$
\begin{gathered}
\sigma_{\mathrm{t}}=\frac{S_{\mathrm{H}}}{2 A_{\mathrm{B}} \cos \theta}-\frac{P_{\mathrm{V}} \sin ^{2} \theta}{2 A_{\mathrm{B}} \sin ^{3} \theta+A_{\mathrm{CL}}} \\
\sigma_{\mathrm{c}}=\frac{S_{\mathrm{H}}}{2 A_{\mathrm{B}} \cos \theta}+\frac{P_{\mathrm{V}} \sin ^{2} \theta}{2 A_{\mathrm{B}} \sin ^{3} \theta+A_{\mathrm{CL}}}
\end{gathered}
$$

ここで， $A_{C L}$ は下部支柱の断面積 である.

倒壊した球形貯槽を対象とした入力值とブレースの応力解析の結果を表 1 に示寸. 加速度は東北地方太平洋沖 地震の実測值の $114 \mathrm{gal}$ とした ${ }^{(1)}$. $F_{\mathrm{H}}$ は修正震度法 ${ }^{(2)}$ により, 固有周期および地域, 地盤種別から求めた応答 倍率と, 減衰による補正係数を地表面加速度に乗じて算出した.

満水の場合を $\mathrm{LPG}$ の場合と比較すると，3 倍程度の大きな応力が生じている．また，圧縮応力の場合が引張応 力の場合よりも応力の值が大きく， 2 倍程度となっている. ブレースの材料は STK400 で，材料規格の降伏点は $235 \mathrm{MPa}$ ，引張強さは 400MPa である. ブレースに引張応力が生じる場合の耐震設計用許容応力は, 降伏点または 引張強さの $70 \%$ のずれか小なる值で，235MPa である. ブレースに圧縮応力が生じる場合の耐震設計用許容応 力は，座屈を考慮して $151 \mathrm{MPa}$ である. LPG の場合は, 引張応力は対応する而震設計用許容応力以下であるが, 圧縮応力は対応する而震設計用許容応力を超える. 満水の場合は, 引張応力と圧縮応力は対応する而震設計用許 容応力を超える. 特に, 圧縮応力は引張強さを超える值となる. しかし, 実際には, 引張灾力が生じる長尺ブレ 一スの延性破壊が先行し, 圧縮応力が生じる短尺ブレースの取付け溶接の分離をもたらしている. したがって, 交差する 2 本のブレースを独立とする耐震設計基準の応力解析の方法には，不備がある.

Table 1 Force and stresses of brace obtained by seismic codes.

\begin{tabular}{|l|r|r|}
\hline & \multicolumn{1}{|c|}{ LPG } & \multicolumn{1}{|c|}{ Water } \\
\hline \hline Horizontal earthquake motion, $K_{\mathrm{H}}$ & 0.114 & 0.114 \\
\hline Weight, $W_{\mathrm{V}}(\mathrm{N})$ & $11,522,467$ & $21,974,394$ \\
\hline Horizontal seismic force, $F_{\mathrm{H}}(\mathrm{N})$ & $3,673,505$ & $7,094,389$ \\
\hline Tensile stress of brace, $\sigma_{\mathrm{t}}(\mathrm{MPa})$ & 81 & 263 \\
\hline Compres sive stress of brace, $\sigma_{\mathrm{c}}(\mathrm{MPa})$ & 178 & 450 \\
\hline
\end{tabular}

\section{4. 鋼管ブレースの破断のメカニズム}

木造建屋では，柱と柱の間に 2 本の角材を斜めに交差させて取付け，補強する．これを筋交い（すじかい）構 造という.この場合に，2本の角材は交差部分で接合しないことが原則であり，2 本の角材は独立とみなせる．引 張力のみを負担し, 圧縮力を負担しないタイロッドブレース構造も, 2 本のタイロッドブレースは独立とみなせ る. 球形貯槽支柱の鋼管ブレース構造を筋交い構造とすれば，交差する 2 本のブレースの軸中心線は食い違い, 取付ける支柱（鋼管）の軸中心線とも一致しない。これは溶接取付けの製作上，不都合である.したがって， 2 本のブレースの一体化溶接構造により, 軸中心線の不一致を解消している. すなわち, 鋼管ブレース構造は筋交 い構造ではなく, 2 本のブレースは独立ではない.

上述した観点から，鋼管ブレースの破断のメカニズムを考察する. 式（1）～（4）に示したように，鋼管ブレ 一ス構造には, 圧縮力 $P_{\mathrm{v}}$ とせん断力 $S_{\mathrm{H}}$ が作用する. 式（3）の引張応力 $\sigma_{\mathrm{t}}$ と式（4）の圧縮応力 $\sigma_{\mathrm{c}}$ の基本的な形 を, 応力の正負を表示して, 以下に示す. 


$$
\begin{aligned}
& \sigma_{\mathrm{t}}=q S_{\mathrm{H}}-r P_{\mathrm{v}} \\
& \sigma_{\mathrm{c}}=-q S_{\mathrm{H}}-r P_{\mathrm{v}}
\end{aligned}
$$

ここで， $q$ と $r$ は構造で決まる定数である. 上式は交差する 2 本のブレースに， せん断力によって一方に正，他 方に負の応力が生じ，圧縮力によって両方に負の応力が生じるという，力学的に当然の結果を示している．以下 では，せん断力に注目して，検討する.

鋼管ブレース構造にせん断力が作用する場合をモデル化して，図 2 (a) に示す.ここで，簡単のために，ブレ 一スの仰角は $\theta=\pi / 4\left(45^{\circ}\right)$ としている. 図 2 (a) では, 長尺ブレースに引張応力が生じるように, せん断力の 作用する方向を定めている. せん断力の作用する方向を逆にすれば，短尺ブレースに引張応力が生じる．材料力 学におけるせん断応力場（せん断応力 $\tau$ ） から二軸主応力場（主応力 $\sigma_{1}, \sigma_{2}$ ）への変換の二次元平面モデルを図 2

（b）に示す ${ }^{(3)}$. 図 2 (a) と（b）は力学的に同じモデルである. したがって，図 2 (c) に示すように，長尺ブ レースには引張りの主応力 $\sigma_{1}=\sigma$, 短尺ブレースには圧縮の主応力 $\sigma_{2}=-\sigma$ が生じる.

$$
\begin{aligned}
& \sigma_{t}=\sigma_{1}=\sigma=\tau \\
& \sigma_{c}=\sigma_{2}=-\sigma=-\tau
\end{aligned}
$$

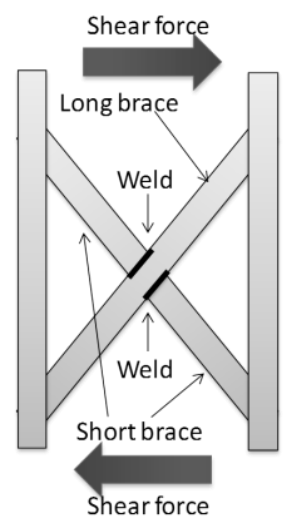

(a)

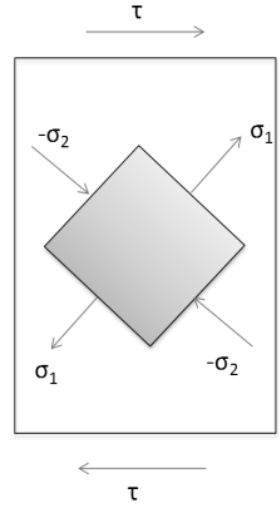

(b)

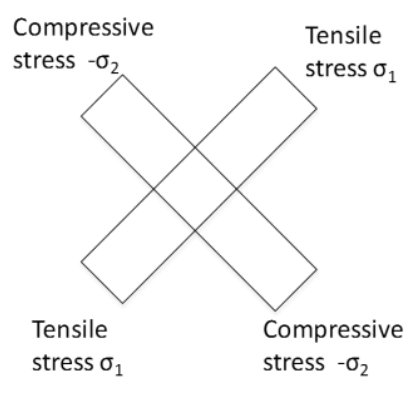

(c)

Fig. 2 Shear force and biaxial stress acting for braces.

一方，板状試験片（または丸棒試験片）の引張りによる延性破壊のメカニズムをモデル化して図 3 に示寸. 塑 性変形を引張方向に $45^{\circ}$ をな, 互いに交差する二つのすべり面の交差すべりでモデル化し, 平行なすべり面群 の作動の継続を仮定すれば，絞り（断面收縮）を伴う延性破壊のメカニズムを表現できる ${ }^{(4)}$.
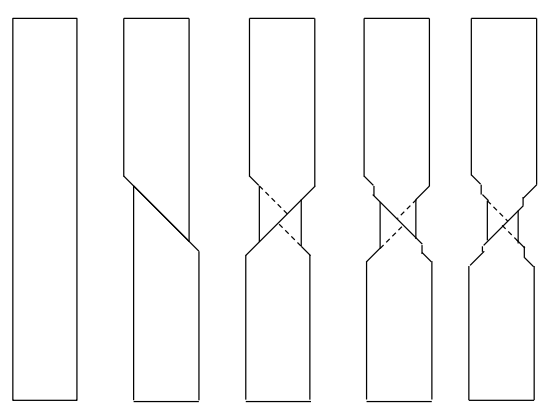

Fig. 3 Mechanism of ductile fracture. 
上記の二つのすベり面の交差すべりを，単一のすべり面のすべりに分離し，さらに二軸応力場 (図 2 (c) 参照) におけるすべり面のすべりへ拡張した結果を図 4 に示す。図 4 において，(a) は板状試験片の引張りによる引張 方向に 45をなすせん断応力面を，（b）は引張りによる二つのすべり面(1)と(2)を，（c）は圧縮による二つのすべ り面(3)と(4)を，(d) は引張りによるすべり面(1)と圧縮によるすべり面(4)の組合せを示している.図 4 (d) の結果 から, 鋼管ブレース構造にせん断力が作用し, 長尺ブレースに引張応力が生じ, 短尺ブレースに圧縮応力が生じ る場合，長尺ブレースと短尺ブレースの交差部分において，長尺ブレースと短尺ブレースに生じるせん断応力が 重畳し，延性破壊の原因となることがわかる．図４において，長尺ブレースに生じる引張応力を $\sigma$, 短尺ブレー スに生じる圧縮応力をー $\sigma$ とすれば，交差部分におけるせん断応力 $\tau$ は，次式で与えられる.

$$
\tau=\frac{\sigma}{2}+\frac{\sigma}{2}=\sigma
$$

多軸応力場の降伏と塑性変形を解析する場合に, 多軸応力を一軸応力に置換える相当応力が用いられる. 二軸 応力場におけるトレスカの相当応力は, 次式で与えられる ${ }^{(3)}$.

$$
\sigma_{\mathrm{eq}, \mathrm{T}}=\sigma_{1}-\sigma_{2}
$$

式（9）に示したせん断応力場 $\left(\sigma_{1}=\sigma, \sigma_{2}=-\sigma\right)$ の場合， $\sigma_{\mathrm{eq}, \mathrm{T}}$ は次式となる.

$$
\sigma_{\mathrm{eq}, \mathrm{T}}=\sigma-(-\sigma)=2 \sigma=2 \tau
$$

トレスカの相当応力は最大せん断応力に対応することが知られており, 図 4 の結果は, トレスカの相当応力を用 いても説明できる. また，式（5）と式（6）に示した圧縮力による圧縮応力は，互いにキャンセルして，相当応 力に寄与しない.

三軸応力場 (主応力 $\left.\sigma_{1}, \sigma_{2}, \sigma_{3}\right)$ において, ミーゼスの相当応力が用いられる. ミーゼスの相当応力は, 次式 で与えられる ${ }^{(3)}$.

$$
\sigma_{\mathrm{eq}, \mathrm{M}}=\left[\frac{1}{2}\left\{\left(\sigma_{1}-\sigma_{2}\right)^{2}+\left(\sigma_{2}-\sigma_{3}\right)^{2}+\left(\sigma_{3}-\sigma_{1}\right)^{2}\right\}\right]^{\frac{1}{2}}
$$

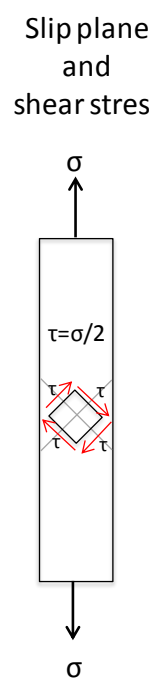

(a)

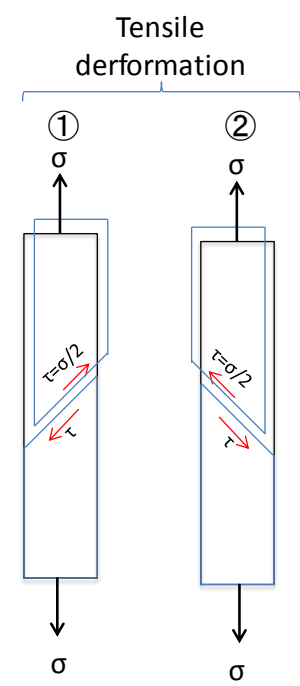

(b)

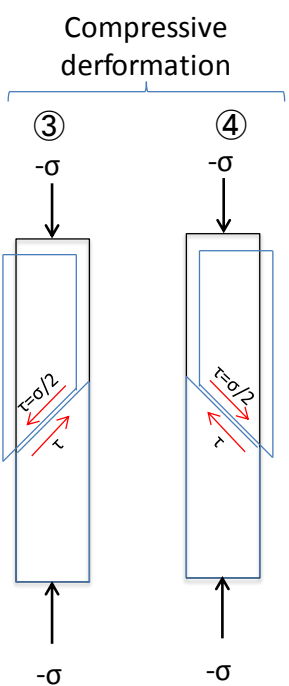

(c)

\section{Slip plane \\ in biaxial stress field}

(5)

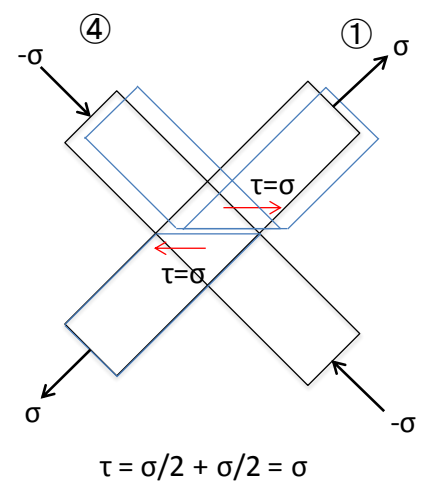

(d)

Fig. 4 Slip plane in biaxial stress field. 
図 4 の結果は, ミーゼスの相当応力を用いても説明できる. これは 5 章で具体的に示寸.

なお，図4（d）のモデル化では，交差部分において，長尺ブレースの引張りの塑性変形と短尺ブレースの圧縮 の塑性変形を識別できない. 鋼管ブレース構造の交差部分の本体は長尺ブレースであり, 軸中心線方向に連続し た形状となっている．これに反して，短尺ブレースは，長尺ブレースによって仕切られた形状である．したがっ て，交差部分においては，長尺ブレースの引張りの塑性変形が優先すると考えられる.

\section{5. 詳細応力解析による検証}

\section{$5 \cdot 1$ 詳細応力解析}

4 章に示した鋼管ブレースの破断のメカニズムを検証するために，倒壞した球形貯槽について，支柱と鋼管ブ レース構造を対象として，有限要素法（FEM）による詳細応力解析を行った. 支柱と鋼管ブレース構造のモデ ル化を図 5 に示す.ブレースの仰角は， $\theta=57.28^{\circ}$ である. 鋼管ブレース構造のモデル化の詳細を図 6 に示す. 図 の(a)はブレース交差部分の外面を示し，図の(b)はブレースの軸中心線を含む断面を示す．長尺ブレースと短尺ブ レースは同一材料，同一寸法の鋼管である．長尺ブレースと交差して取付ける 2 本の短尺ブレースは，長尺ブレ 一スの外周に完全に一致する形状で一体化し，溶接などの実際の詳細形状のモデル化は省略した.

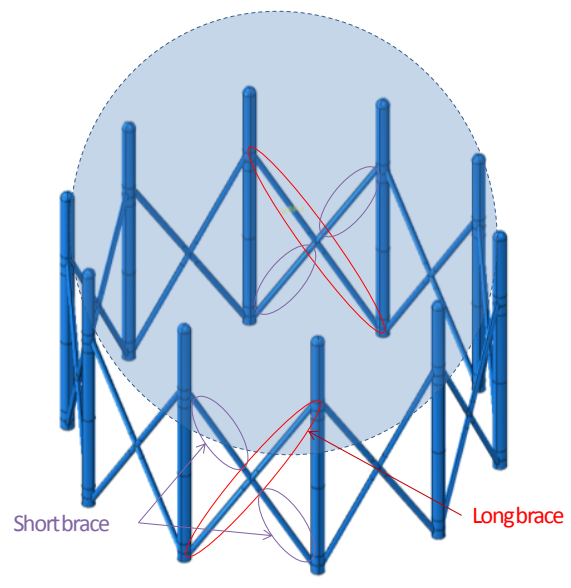

(a)

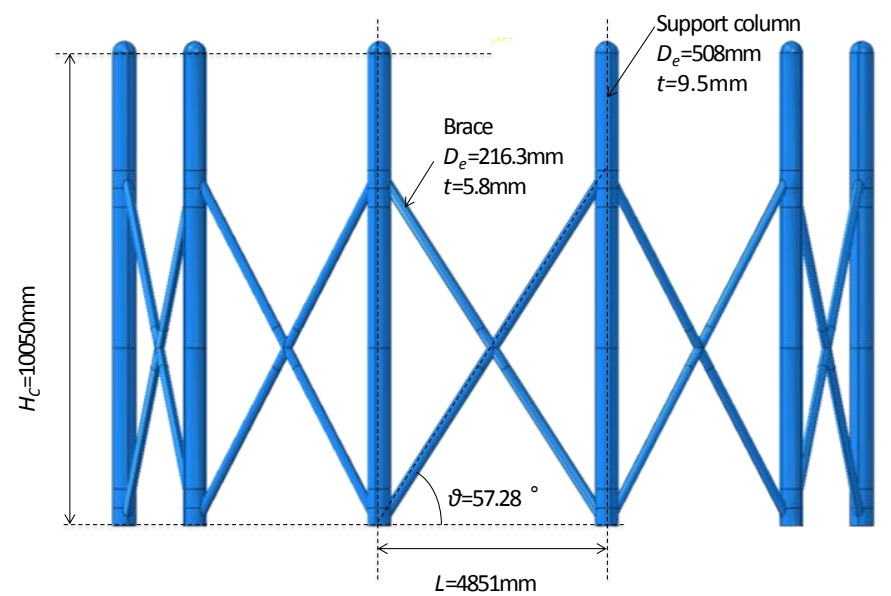

(b)

Fig. 5 Modeling of support structure of spherical tank for FEM analysis.

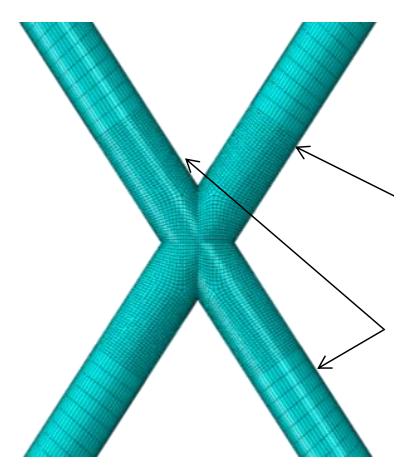

(a) Outer surface

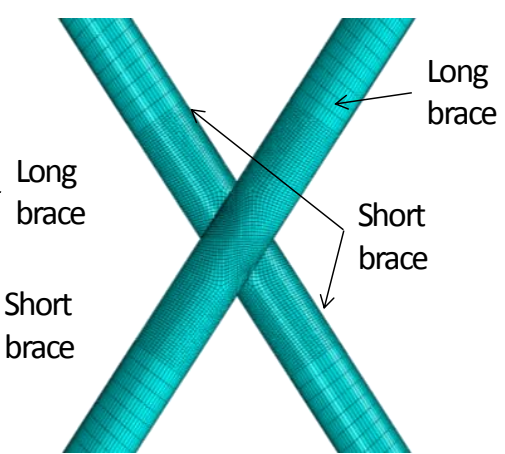

(b) Cross section

Fig. 6 Modeling of pipe brace structure for FEM analysis.

FEM 解析には, 汎用構造解析プログラム（ダッソーシステム社の ABAQUS6.11-1）を用いた. 三次元の低減積 分シェル二次要素（S8R）を用い, 要素数は 310,744 , 節点数は 930, 842 である. FEM 解析は弾性解析とし, 縦弾 性係数は $E=205 \mathrm{GPa}$ ，ポアソン比はv $v 0.3$ である. 境界条件は，下部支柱をベースプレートで固定支持とし，球 
殼の中心位置に $W_{\mathrm{V}}$ と $F_{\mathrm{H}}$ を与え, 球款の中心位置と 10 本の上部支柱の上端を多点拘束により結合した. 入力值 は表 1 に示した満水の場合の $W_{\mathrm{V}}$ および $F_{\mathrm{H}}$ とした. $W_{\mathrm{V}}$ は鉛直方向下向とし， $F_{\mathrm{H}}$ は相対する位置にある 2 組のブ レースに対して平行となる水平方向に与えた. FEM解析により得られた応力は, ブレースの交差部分では, 長尺 ブレースの軸中心線方向に垂直な断面におけるミーゼスの相当応力で, 交差部分から離れた断面では, 長尺ブレ 一スと短尺ブレースのそれぞれについて軸中心線方向の垂直応力で表示した.

FEM 解析により得られた最大応力が生じる鋼管ブレース構造の位置を, 図 7 に示寸. せん断力（水平地震力） 方向に平行で相対する位置にある 2 組の鋼管ブレース構造に，最大応力が生じる．この場合に，支柱の中心を通 る円の周上に沿って，鋼管ブレース構造は規則的に配置し，相対する位置で長尺ブレースの方向は逆になる．し たがって, 相対する位置にある長尺ブレースは, 一方が引張応力を生じ, 他方が圧縮応力を生じる. せん断力方 向が反転すれば，上記の長尺ブレースの応力も正負が反転する. 2 章で示したブレース損傷事例のうちで, 相対 する位置の 2 本の長尺ブレースが損傷した事例では, せん断力方向の反転が繰り返され，最大引張応力が生じる 長尺ブレースのみが損傷した結果と考えられる.

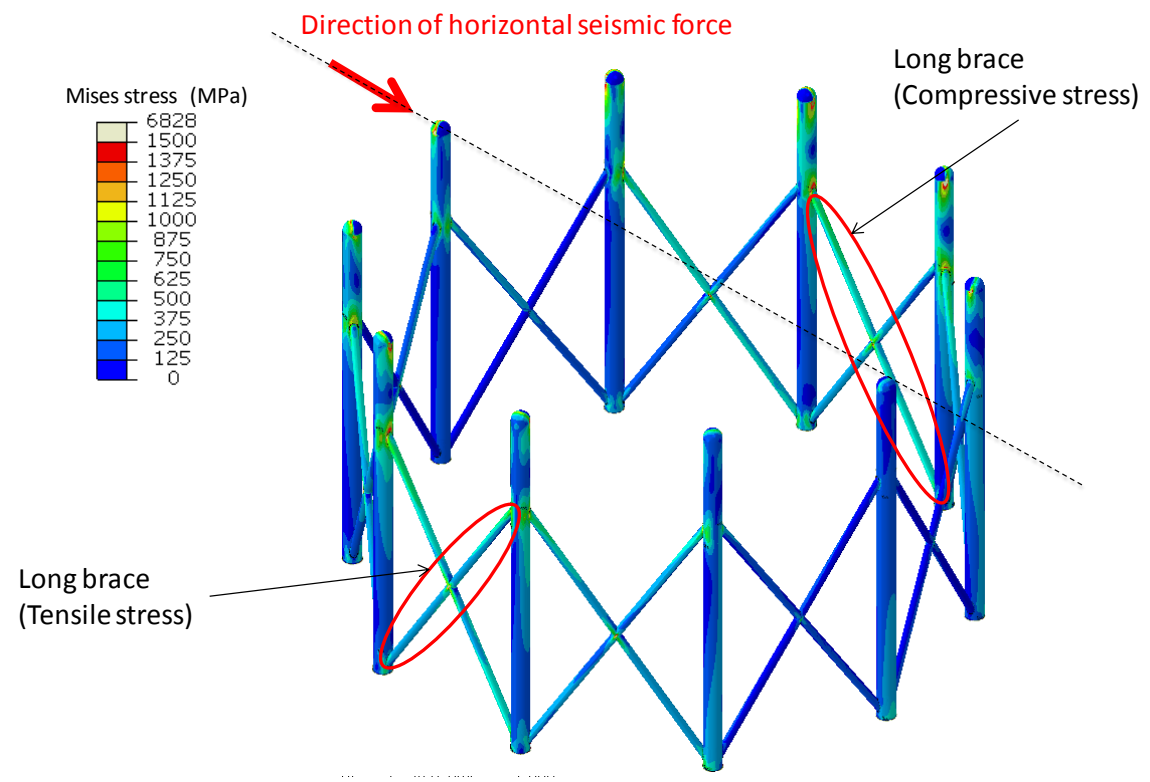

Fig. 7 FEM results showing maximum stress position of braces.

長尺ブレースに最大引張応力が生じる場合に, ブレースの交差部分から離れた上部および下部の断面において, ブレースの軸中心線方向の垂直応力の分布を図 8 に示寸. ここで, 横軸はブレースの周方向位置を基準化して示 寸 (周長=1). 長尺ブレースには引張応力が，短尺ブレースには圧縮応力が生じる.ブレースの厚さ方向には, 応力は均一に分布する. ブレースの周方向の応力分布は, 貯槽側（inside）と外側 (outside) で対称形を示す. 長 尺ブレースの場合, 引張応力は上部において位置 0 付近で最大值 (416MPa) と位置 0.5 付近で最小值 (253MPa) を，下部において位置 0.5 付近で最大值（362MPa）と位置 0 付近で最小值（291MPa）を示している.これらの 数值から線形応力分布を仮定して計算すれば, 長尺ブレースは軸中心線方向の引張力に加えて, ブレースの交差 部分で反転する曲げモーメントを受けており, 上部の結果と下部の結果を平均して, 引張応力 $(+331 \mathrm{MPa})$ と曲 げ応力（ $\pm 59 \mathrm{MPa} ）$ の組合せ応力とみなせる．短尺ブレースの場合も同様に計算すれば，短尺ブレースは軸中心線 方向の圧縮力に加えて，ブレースの交差部分で反転する曲げモーメントを受けており，上部の結果と下部の結果 を平均して, 圧縮応力 $(-394 \mathrm{MPa})$ と曲げ応力（ $(57 \mathrm{MPa} ）$ の組合せ応力とみなせる. 長尺ブレースが受ける曲 げモーメントと短尺ブレースが受ける曲げモーメントはブレースの交差部分においてつり合いの状態にあり, 長 尺ブレースと短尺ブレースに生じる曲げ応力は等しい.

3 章の表 1 に示した耐震設計基準による応力解析の結果を FEM 解析による結果と比較すれば, 耐震設計基準に よる応力解析の結果は FEM 解析による結果を, 長尺ブレースが引張応力の場合には過小評価し（263MPa < $331 \mathrm{MPa})$, 短尺ブレースが圧縮応力の場合には過大評価している（450MPa > 394MPa）. 
上述した長尺ブレースの場合に対して，相対する位置にある長尺ブレースの場合には，長尺ブレースに最大圧 縮応力が生じ，短尺ブレースに最大引張応力が生じる．この場合に，FEM解析の結果の表示は省略する. 相対す る位置において最大応力を比較寸れば，最大引張応力は短尺ブレースの場合が長尺ブレースの場合よりもやや小 さく，最大圧縮応力の絶対值は長尺ブレースの場合が短尺ブレースの場合よりもやや大きい.
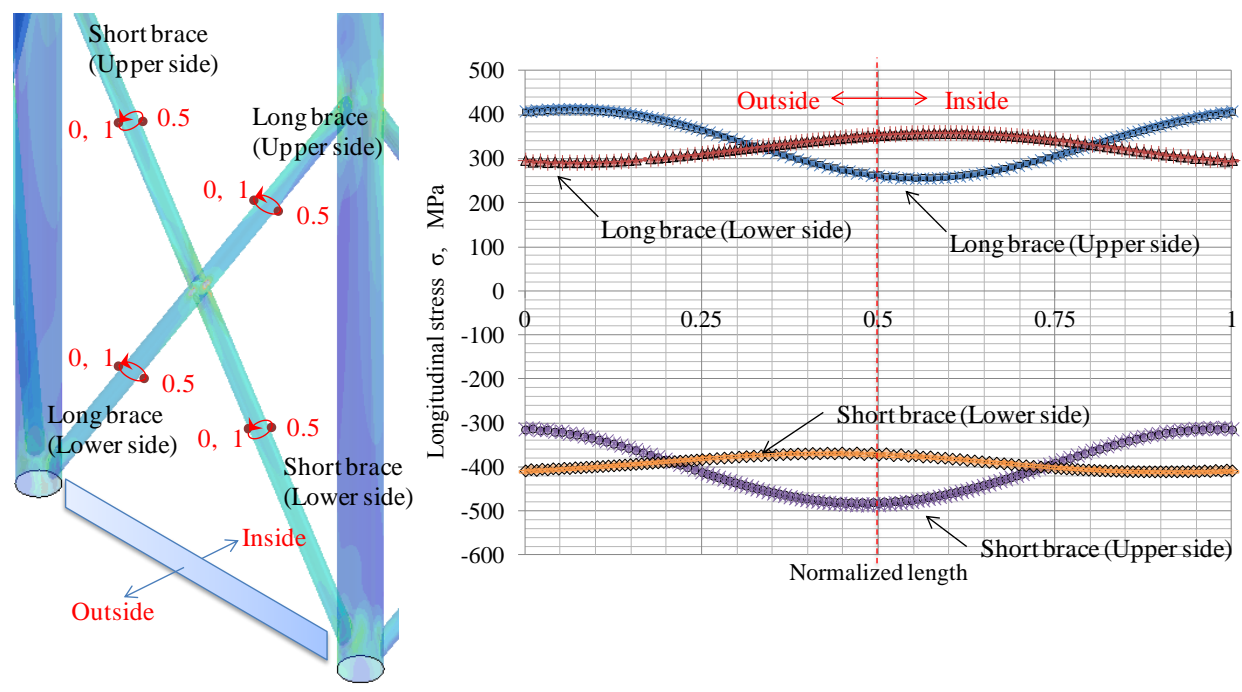

Fig. 8 FEM results showing longitudinal stress distribution in long and short braces.

長尺ブレースに最大引張応力が生じる場合に，ブレースの交差部分で長尺ブレースの軸中心線方向に垂直な断 面において，ミーゼスの相当応力の分布を図 9 に示す，ここで，横軸は長尺ブレースの周方向の位置を基準化し て示す (周長=1). また, 長尺ブレースの厚さ方向の位置を内面 (internal), 中央 (middle), 外面 (external) で 示す．長尺ブレースの周方向の応力分布は，貯槽側（inside）と外側（outside）で対称形を示すが，貯槽側のほう

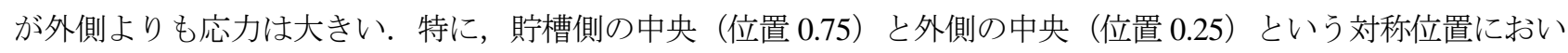
て，応力分布にピークを示している．応力は長尺ブレースの厚さ方向にも分布しており，内面での応力は鋭いピ ークを示しているが，外面での応力は鋭いピークを示していない．図 6 に示した長尺ブレースと短尺ブレースの 交差形状のモデル化を参照して，2 本の短尺ブレースの取付け端面はリング状曲面で, 長尺ブレースの外面に一 体化接合されている. また, 2 本の短尺ブレースの取付け端面同士は, 長尺ブレースの貯槽側の中央と外側の中 央という対称位置において，局所的に一体化接合されている．したがって，長尺ブレースの外面での周方向応力 分布は, 短尺ブレースからの圧縮応力の伝達と外面における付加的な厚さの増減（形状変化）に起因している. また, 長尺ブレースの内面での周方向応力分布（鋭いピーク）は，外面における形状不連続による応力集中に起 因している.
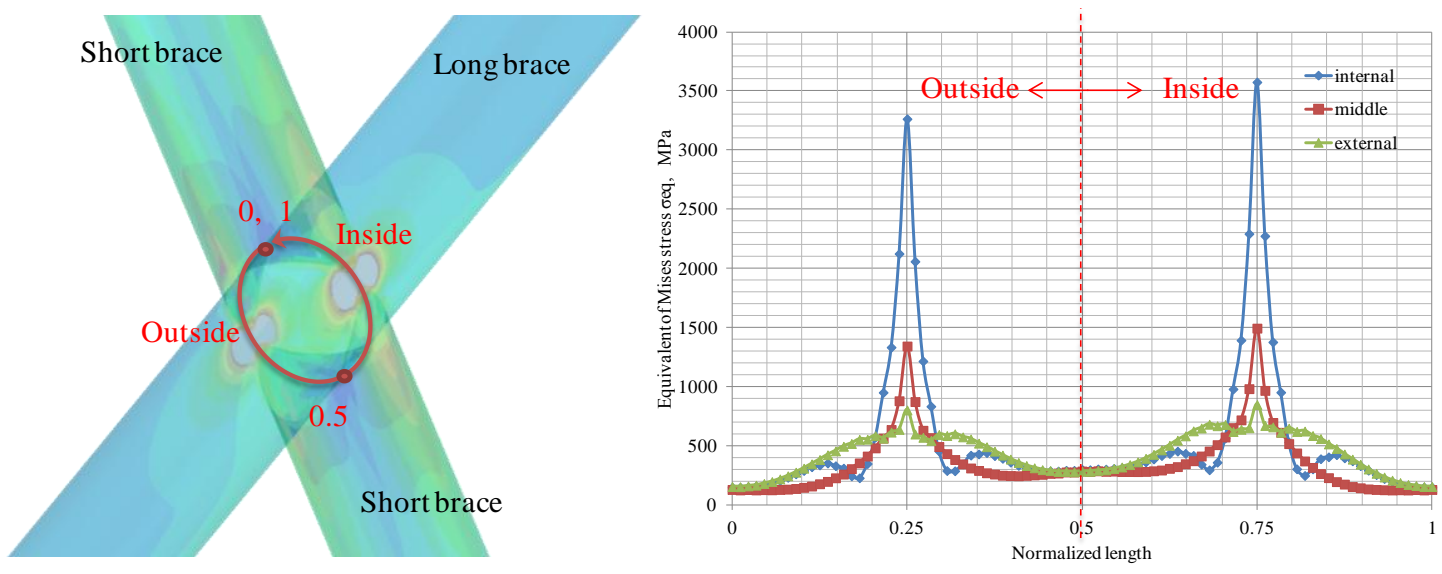

Fig. 9 FEM results showing Mises stress distribution in crossed part of two braces. 
なお，ブレースの交差部分での長尺ブレースの任意断面における相当応力分布は，軸中心線方向と断面のなす 角度によって変化する. FEM 解析の結果の表示は省略するが, 軸中心線方向と垂直な断面における結果と, 軸中 心線方向と $\theta=57.28^{\circ}$ （ブレースの仰角）をな寸断面（鉛直方向に垂直な断面）における結果に，大きな差異はな い.

長尺ブレースに最大圧縮応力が生じる場合に, FEM 解析の結果の表示は省略寸る. ブレースの交差部における ミーゼスの相当応力の分布は，長尺ブレースに最大引張応力が生じる場合の結果とほぼ同様であるが，ミーゼス の相当応力は小さくなる. 一方, 前述したように, ブレースの交差部分から離れた断面において, 最大圧縮応力 の絶対值は長尺ブレースの場合が短尺ブレースの場合よりもやや大きい. 寸なわち，ブレースの交差を考慮しな い場合には，長尺ブレースに最大圧縮応力が生じる場合が而震設計における限界状態となるが，ブレースの交差 を考慮する場合には, 長尺ブレースに最大引張応力が生じる場合が耐震設計における限界状態となる，これは 4 章の結論を定量的に検証する結果である.

実際の溶接構造は一体化接合ではないので，上述したピーク応力はかなり軽減される．また，ピーク応力は塑 性変形によって消失し, 延性破壊には影響しない (4).したがって, 以下では, ピーク応力を対象とする検討はし ない.

図 9 を参照して，ブレースの交差部分の断面において，内面，中央および外面を評価ラインとし，周方向の応 力分布を数值積分して, ミーゼスの相当応力の平均值を算出した. 内面における平均值は $551 \mathrm{MPa}$, 中央におけ る平均值は $358 \mathrm{MPa}$ ，外面における平均値は $443 \mathrm{MPa}$ ，全体の平均值は $451 \mathrm{MPa}$ である. 以上の結果から, ブレー スの交差部分において，ミーゼスの相当応力の平均值はブレースの交差部分から離れた断面における垂直応力の 值をはるかに超え，材料の引張強さの值（400MPa）に達しており，延性破壊の原因となったことが検証された.

\section{$5 \cdot 2$ 相当応力の簡易解析}

前述したように, ブレースの交差部分から離れた断面において, 長尺ブレースの引張応力は $\sigma_{\mathrm{t}}=331 \mathrm{MPa}$, 短尺 ブレースの圧縮応力は $\sigma_{\mathrm{c}}=-394 \mathrm{MPa}$ である. この $\sigma_{\mathrm{t}}$ と $\sigma_{\mathrm{c}}$ を用いて, ブレースの交差部分における簡易的な相当応 力の解析を行う。

2 つの解析モデルを図 10 に示寸. FEM 解析の場合と同様に, 相当応力の評価断面を長尺ブレースの軸中心線 方向に垂直な断面（断面積 $A$ ）とする. 2 つ解析モデルは, 評価断面は同じであるが, 短尺ブレースの応力成 分の寄与を計算する断面積の大きさが異なる．モデル 1 は短尺ブレースの忘力成分が，そのまま評価断面に生じ ていると考える（断面積 $A / \cos \alpha ）$ ，モデル 2 は短尺ブレースの力成分が，評価断面に応力を生じると考える（断面 積 $A$ ).

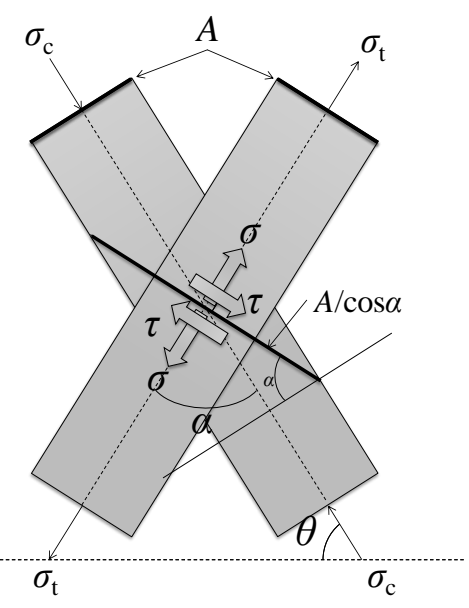

(a) Model 1

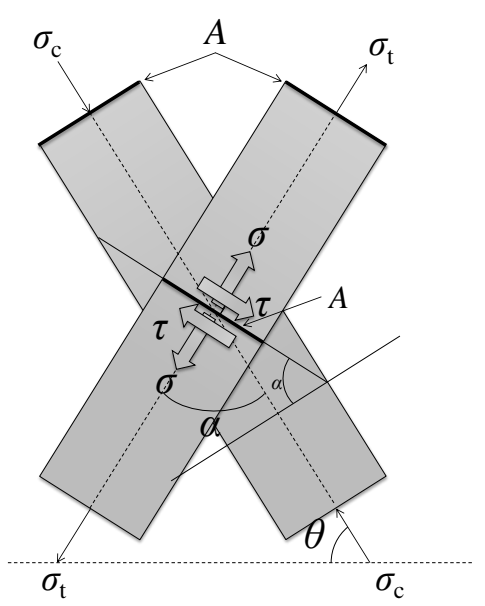

(b) Model 2

Fig. 10 Schematic of analytical model (a) model 1, (b) model 2.

ここで， $\alpha$ は長尺ブレースと短尺ブレースがなす角度で，次式で与えられる． 
$\alpha=180-2 \theta=65.44^{\circ}$

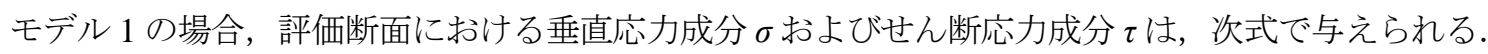

$$
\begin{aligned}
& \sigma=\sigma_{\mathrm{t}}-\sigma_{\mathrm{c}} \cos ^{2} \alpha \\
& \tau=\sigma_{\mathrm{c}} \sin \alpha \cos \alpha
\end{aligned}
$$

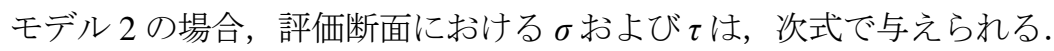

$$
\begin{aligned}
& \sigma=\sigma_{\mathrm{t}}-\sigma_{\mathrm{c}} \cos \alpha \\
& \tau=\sigma_{\mathrm{c}} \sin \alpha
\end{aligned}
$$

評価断面におけるトレスカの相当応力は式（18）で，ミーゼスの相当応力は式（19）で与えられる. よく知ら れているように， $\sigma_{\mathrm{eq}, \mathrm{T}}>\sigma_{\mathrm{eq}, \mathrm{M}}$ である。

$$
\begin{aligned}
& \sigma_{\mathrm{eq}, \mathrm{T}}=\sqrt{\sigma^{2}+4 \tau^{2}} \\
& \sigma_{\mathrm{eq}, \mathrm{M}}=\sqrt{\sigma^{2}+3 \tau^{2}}
\end{aligned}
$$

モデル 1 とモデル 2 の相当応力の簡易解析の結果を, FEM 解析の結果と比較して表 2 に示寸. モデル 1 は, 長 尺ブレースの評価断面に対して，短尺ブレースの断面積を過大評価しており（実体の断面ではない）, 相当応力は 過小評価となる. モデル 2 は, 長尺ブレースの評価断面に対して, 短尺ブレースの断面積を過小評価しており（短 尺ブレースの応力分担を無視), 相当応力は過大評価となる. ミーゼスの相当応力の場合, FEM 解析の平均值

(451MPa) はモデル 1 の結果（368MPa）とモデル 2 の結果（643MPa）の中間に位置する. また，モデル 2 の結 果 (643MPa) は, FEM 解析結果の内面における平均值 (551MPa) に近い. すなわち, ブレースの交差部分にお けるミーゼスの相当応力の平均值は，2 本のブレース（長尺と短尺）の交差部分から離れた断面における FEM 解 析結果の応力（または耐震設計基準による応力解析結果の応力）から，モデル 2 を適用して的確に簡易解析でき る.

以上は，満水の場合の FEM 解析の結果である. LPG の場合に，FEM 解析の結果の表示は省略する． 3 章の表 1 に示した耐震設計基準による応力解析の結果を用いて説明する. 長尺ブレースの引張応力は $\sigma_{\mathrm{t}}=81 \mathrm{MPa}$ ，短尺ブ レースの圧縮応力は $\sigma_{\mathrm{c}}=178 \mathrm{MPa}$ である.この $\sigma_{\mathrm{t}}$ と $\sigma_{\mathrm{c}}$ を用いて相当応力を計算する. トレスカの相当応力は式(18) から 324MPa，ミーゼスの相当応力は式（19）から 280MPa となる.これらの值はブレースに引張応力が生じる 場合の耐震設計用許容応力 $235 \mathrm{MPa}$ より大きな值であり，材料の降伏点の実測值とほぼ等しい. 実際に, LPG の 場合のブレースの損傷事例があることは，2 章に示した.

Table 2 Tresca and Mises stresses obtained by simple stress analysis.

\begin{tabular}{|l|c|c|}
\hline & $\begin{array}{c}\text { Tresca stress } \\
\sigma_{\text {eq, }}(\mathrm{MPa})\end{array}$ & $\begin{array}{c}\text { Mises stress } \\
\sigma_{\text {eq,M }}(\mathrm{MPa})\end{array}$ \\
\hline \hline FEM & 491 & 451 \\
\hline Model 1 & 397 & 368 \\
\hline Model2 & 736 & 643 \\
\hline
\end{tabular}




\section{6. 今後の対策の指針と課題}

本研究では, 球形貯槽支柱の鋼管ブレースの破断事例について, メカニズムを解明し, 詳細応力解析により検 証した．同じ形式の鋼管ブレース構造をもつ既設の球形貯槽は，国内で 100 基を超えると想定されている．同種 事故再発防止のために，今後の対策の指針は下記の 2 つに尽きる.

（1）既設の球形貯槽のすべてを対象として，2 本のブレースの交差部分において，相当応力の解析を行い，耐震 性能を検討する．而震性能が不十分な場合には，対策として有効な補強を施工する。

(2) 新設の球形貯槽への対策として, 而震設計基準を改正し， 2 本のブレースの交差部分において，相当応力の 解析方法を明示する.

上記の対策の指針を実行するための課題を下記に示す.

（3）球形貯槽支柱と鋼管ブレース構造は，貯槽容量に伴い形式と寸法が異なる. 形式と寸法を類型化し，詳細応 力解析を行い，相当応力の解析方法を定式化する必要がある.

(4) 球形貯槽支柱と鋼管ブレース構造の補強方法を類型化して, 詳細応力解析を行い, 補強の有効性を検証する 必要がある.この場合に，ブレースの交差部分の補強のみならず，支柱への取付け部分の補強も考慮し，剛 性に及ぼす補強の効果も検討する.

(5) 本研究では, FEM 解析は弾性解析とした. 而震設計基準, レベル 1 而震性評価は弾性設計であるから, 特に 弾塑性解析の必要はないと考えられる。しかし, レベル 2 耐震性評価と延性破壊のメカニズムの追求という 観点からは，弾塑性解析を行う意義はある．弾塑性解析に際しては，計算時間との関連において，ブレース の交差部分を抽出し，適切にモデル化することが必要となる.

\section{7. 結}

球形貯槽支柱の鋼管ブレースの破断事例についてメカニズムを考察し，鋼管ブレース構造の詳細応力解析によ ってメカニズムを検証し，さらに現行の耐震設計基準について検討した．結果を以下に要約する.

(1) 既設の鋼管ブレースの耐震性能は, 2 本のブレース（長尺と短尺）の交差部分において不十分な場合がある.

（2） 2 本のブレースの交差部分では，多軸応力場の相当応力（せん断応力）が増大し，塑性変形による破断（延 性破壞）の原因になる.

（3）長尺ブレースに引張応力が生じる場合に，長尺ブレースの破断が先行し，短尺ブレースの取付け溶接が分離 する.

（4）現行の耐震設計基準による応力解析結果を用いて, ブレースの交差部分における相当応力を簡便に評価する 方法を示し，その有効性を有限要素法（FEM）による詳細応力解析の結果で検証した.

\section{謝 辞}

本研究には平成 23 年度経済産業省委託事業の内容が含まれており, 総合資源エネルギー調查会高圧ガス及び火 薬類保安分科会第 18 回高圧ガス部会（平成 23 年 11 月 29 日）で一部を報告している。また，コスモ石油㑣と鹿 島石油㑣には, 情報と資料の提供をいただいた. 高圧ガス保安協会, 赤塚広隆氏, 上田洋平氏には調査と検討に, 竹花立美氏は FEM 解析にご助力いただいた，以上を記して，関係各位に謝意を表する.

\section{文献}

（1）佐野尊，上田洋平，赤塚広隆，小林英男，“LPG 球形貯槽の倒壊による火災及び爆発”，高圧ガス，Vol.49，No.6， (2012), pp.457-467.

（2）高圧ガス設備等而震設計指針(2012） レベル 1 而震性能評価（耐震設計設備・基礎）編，(2012)，高圧ガス保安協 会.

（3）例えば, 小林英男, 轟 章, 固体の弾塑性力学, (2007), 数理工学社.

（4）小林英男, 破壊力学, (1993), 共立出版. 